\title{
Monoclonal Gammopathy among Patients with Chronic Hepatitis C Infection
}

\author{
Salem H. Al-Shemmari ${ }^{a}$ lqbal Siddique ${ }^{a}$ Fuad Hassan $^{a}$ \\ David Nkansa-Dwamena $^{b}$ Hisham Abu El-Nagab Reem Ameen ${ }^{c}$ \\ ${ }^{a}$ Department of Medicine, Faculty of Medicine, Kuwait University, ${ }^{b} \mathrm{Al}-A m i r i$ Hospital, and ${ }^{\mathrm{c}}$ Central Blood Bank, \\ Kuwait
}

\section{Key Words}

Monoclonal gammopathy $\cdot$ Hepatitis $\mathrm{C}$ virus $\cdot$ Interferon

\begin{abstract}
Objective: To determine the prevalence of monoclonal gammopathies in Kuwait and its association with chronic hepatitis C virus (HCV) infection. Methodology: Serum protein electrophoresis and measurement of immunoglobulin levels were carried out prospectively in 100 consecutive patients with chronic HCV infection. Results: Among the 100 patients tested (82 males, 18 females; median age 45 years), 59 had polyclonal band in serum protein electrophoresis while the other 41 had a normal pattern. None of the patients had monoclonal gammopathy. The mean serum immunoglobulin levels were: IgG $18.4 \mathrm{~g} / \mathrm{l}$ (range 4-39), IgA $2.9 \mathrm{~g} / \mathrm{l}$ (range 0.09-8) and $\lg \mathrm{M}$ $1.6 \mathrm{~g} / \mathrm{l}$ (range 0.14-6.08). Conclusion: There was no evidence of monoclonal gammopathies in patients with chronic HCV infection in Kuwait.
\end{abstract}

Copyright (c) 2004 S. Karger AG, Basel

\section{Introduction}

The clinical course of chronic hepatitis $\mathrm{C}$ virus (HCV) infection is often associated with extrahepatic manifestations. Hematological consequences of HCV infection include essential mixed cryoglobulinemia (EMC) and lymphoma [1, 2]. EMC is the most common extrahepatic manifestation of $\mathrm{HCV}$ infection and often occurs in patients with long-standing infection [3]. However, there is no obvious association between EMC and specific HCV genotype $[4,5]$. There are several studies that link lymphoma with HCV infection in both HCV-related type II EMC subjects and also in patients without EMC [6-10]. The issue of monoclonal gammopathies among patients with chronic $\mathrm{HCV}$ is controversial and there seems to be some regional variation [11-13]. Therefore, the present study examined patients with a long-standing HCV infection and studied the effect of interferon- $\alpha$ on the prevalence of monoclonal gammopathies.

\section{Patients and Methods}

From November 2000 to January 2001, all known confirmed cases of chronic $\mathrm{HCV}$ in Kuwait at the time were recruited for the study. These patients came from Thunayan $\mathrm{Al}$ Ghanim Center and Mubarak Al Kabir Hospital, the main gastrohepatology centers in

Dr. Salem Al-Shemmari

Department of Medicine

Faculty of Medicine, Kuwait University

PO Box 24923, 13110 Safat (Kuwait)

Tel. +965 5319596, Fax +965 5338907, E-Mail salemalshemmari@hotmail.com 
Table 1. Patient characteristics and laboratory investigations

\begin{tabular}{|c|c|c|c|}
\hline Characteristics & $\begin{array}{l}\text { All patients } \\
(\mathrm{n}=100)\end{array}$ & $\begin{array}{l}\text { Interferon } \\
\text { therapy } \\
(\mathrm{n}=44)\end{array}$ & $\begin{array}{l}\text { No interferon } \\
\text { therapy } \\
(\mathrm{n}=56)\end{array}$ \\
\hline Median age, years (range) & $45(11-70)$ & $45(16-63)$ & $45(11-70)(\mathrm{p}=0.6)$ \\
\hline \multicolumn{4}{|l|}{ Gender } \\
\hline Males (\%) & 82 & $36(81.8 \%)$ & $46(82.2 \%)$ \\
\hline Females $(\%)$ & 18 & $8(18.2 \%)$ & $10(17.8 \%)$ \\
\hline \multicolumn{4}{|l|}{ Nationality } \\
\hline Kuwaiti (\%) & 20 & $10(22.7 \%)$ & $10(17.8 \%)$ \\
\hline Non-Kuwaiti Arabs (\%) & 77 & $33(75 \%)$ & $44(78.6 \%)$ \\
\hline Others $(\%)$ & 3 & $1(2.3 \%)$ & $2(3.6 \%)$ \\
\hline $\begin{array}{l}\text { Median duration since diagnosis, } \\
\text { months (range) }\end{array}$ & $48(3-168)$ & $48(5-132)$ & $48(3-168)$ \\
\hline \multicolumn{4}{|l|}{ SPE } \\
\hline Normal & 59 & 30 & 29 \\
\hline Polyclonal & 41 & 14 & $27 \quad(\mathrm{p}=0.07)$ \\
\hline Monoclonal & 0 & 0 & 0 \\
\hline \multicolumn{4}{|l|}{ Mean serum immunoglobulin, $\mathrm{g} / \mathrm{l}$} \\
\hline $\operatorname{IgG}$ & 18.4 & 17.8 & $18.7(\mathrm{p}=0.4)$ \\
\hline IgA & 2.9 & 3.2 & $2.8(\mathrm{p}=0.2)$ \\
\hline $\operatorname{IgM}$ & 1.6 & 1.5 & $1.8(\mathrm{p}=0.2)$ \\
\hline
\end{tabular}

$\mathrm{p}$ values refer to differences between groups receiving interferon therapy and those that did not receive this treatment.
Kuwait. Chronic HCV infection was diagnosed on the basis of serum positivity for anti-HCV antibodies using a second-generation enzyme-linked immunosorbent assay (ELISA), the presence of $\mathrm{HCV}$ RNA in blood and elevated serum alanine aminotransferase level in the absence of other causes of liver disease.

\section{Laboratory Testing for Immunoglobulins}

Serum protein electrophoresis (SPE) was performed on agarose gels (Beckman Paragon SPE) and serum immunoglobulin levels were measured by using rate nephelometry (Beckman Array). A sample from a known case of monoclonal gammopathy was run as a positive control in SPE.

\section{Statistical Analysis}

Data analysis was performed using SPSS statistical software version 11 (SPSS Inc., Chicago, Ill., USA). A p value of $\leq 0.05$ was considered statistically significant. Student's nonpaired t test was used to compare the different patient groups.

\section{Results}

The study comprised 100 patients with chronic $\mathrm{HCV}$ infection. Patients' characteristics are shown in table 1. There were 82 males and 18 females with a median age of 45 years. The median duration from the time of HCV diagnosis was 48 months (range 3-168). The majority of patients were non-Kuwaiti Arabs (75\%). A total of 44 patients had previously received combination anti-HCV treatment with interferon and ribavirin without sustained response. Interferon was given for a minimum of 3 months, and responding patients were given an extra 3 months of interferon therapy. Liver biopsies were performed in all the patients who received interferon and in 30 of the 54 patients who did not get interferon. SPE showed polyclonal bands in a total of 41 patients [14/44 $(31.8 \%)$ in the interferon group and $27 / 56(42.2 \%)$ in the no-interferon group]. The difference between the two groups was not statistically significant $(p=0.07)$. A total of 59 patients [30/44 (68.2\%) in the interferon group and $29 / 56(51.7 \%)$ in the no-interferon group] had a normal SPE. No patient was found to have a monoclonal band on SPE pattern. The mean serum IgG level was $18.4 \mathrm{~g} / \mathrm{l}$ (range 4-39), IgA $2.9 \mathrm{~g} / 1$ (range 0.09-8) and IgM $1.6 \mathrm{~g} / \mathrm{l}$ (range 0.14-6.08). Immunoglobulin levels were not significantly different between the two groups.

\section{Discussion}

The prevalence of monoclonal gammopathies among patients with chronic HCV infection is controversial. In the study by Andreone et al. [12], a monoclonal band was 
detected in $11 \%$ of $\mathrm{HCV}$-positive patients, while Mangia et al. [11] showed that the prevalence of monoclonal gammopathies in patients with chronic HCV infection without cryoglobulinemia did not seem to differ from that in the general population. However, the latter study did not report the characteristics of the study sample or the methods used to screen for monoclonal gammopathy. Further, an in vitro study has shown that interferon- $\alpha$ may interfere with the production of monoclonal bands [14]. The present study clearly defines the patient population. Results were analyzed separately for patients who received interferon- $\alpha$ and those who did not. None of these cases had monoclonal gammopathy. These findings are in agreement with Mangia et al. [11] in terms of a low prevalence of monoclonal gammopathies associated with hepatitis $\mathrm{C}$. These data also showed that interferon suppressed the polyclonal proliferation of $\mathrm{B}$ lymphocytes. It was not possible for us to obtain viral genotypes in our patients to assess the role of this factor in paraproteinemia. However, it is known that the majority of $\mathrm{HCV}$ patients in our region are infected with genotype $4[15,16]$. A common source of infection might have been the use of unsterilized needles to treat Bilharzia.

The absence of monoclonal gammopathies reported in this study could be due to the fact that monoclonal gammopathies are diseases of the elderly. The prevalence of this condition in individuals between 25 and 65 years of age is about $1 \%$ in the general population and most of our patients are young. It has been reported previously that the detection rate of monoclonal protein in Kuwait is very low [17].

Although this study showed no statistical differences between the two groups of patients (with and without interferon), the interferon treatment group had a lower incidence of polyclonal immunoglobulin production compared to the no-interferon group.

In conclusion, our results show that the prevalence of monoclonal gammopathies in patients with chronic $\mathrm{HCV}$ liver disease is extremely low and hence routine screening of these patients for monoclonal bands may not be necessary in Kuwait.

\section{References}

1 Agnello V, Chung RT, Kaplan LM: A role for hepatitis C infection in type II cryoglobulinemia. N Engl J Med 1992;327:1490-1495.

2 Brind AM, Watson JP, Burt A, Kestevan P, Wallis $\mathrm{J}$, Proctor SJ, Bassendine MF: NonHodgkin's lymphoma and hepatitis $\mathrm{C}$ virus infection. Leuk Lymphoma 1996;21:127-130.

3 Lunel F, Musset L: Hepatitis C virus infection and cryoglobulinemia. J Hepatol 1998;29:848855.

4 Pawlotsky JM, Roudot-Thoraval F, Simmonds P, Mellor J, Ben Yahia MB, Andre C, Voisin MC, Intrator L, Zafrani ES, Duval J: Extrahepatic immunologic manifestations in chronic hepatitis $\mathrm{C}$ and hepatitic C serotypes. Ann Intern Med 1995;122:169-173.

5 Zignego AL, Ferri C, Giannini C, Monti M, La Civita L, Carecia G, Longombardo G, Lombardini FD, Bombardieri S, Gentilini P: Hepatitis $\mathrm{C}$ virus genotype analysis in patients with type II mixed cryoglobulinemia. Ann Intern Med 1996;124:31-34.

6 Pozzato G, Mazzaro C, Carvatto M, Modalo ML, Ceseli S, Mazzi G, Sulfaro S, Franzin F, Tulissi P, Moretti M: Low grade malignan lymphoma, hepatitis $\mathrm{C}$ virus infection, and mixed cryoglobulinemia. Blood 1994;84:30473053.
7 Ferri C, Monti M, La Civita L, Careccia G, Mazzaro C, Longombardo G, Lombardini F, Greco F, Pasero G, Bombardieri S: Hepatitis C virus infection in non-Hodgkin's B-cell lymphoma complicating mixed cryoglobulinemia. Eur J Clin Invest 1994;24:781-784.

8 Zignego AL, Ferri C, Giannini C, La Civitia L, Careccia G, Longombardo G, Lombardini F, Bombardieri S, Gentilini P: Hepatitis C virus infection in mixed cryoglobulinemia and B-cell non-Hodgkin's lymphoma: Evidence for pathologic role. Arch Virol 1997;142:545-555.

9 Izumi T, Sasaki R, Tsunoda S, Akutusu M, Okamoto H, Miura Y: B cell malignancy and hepatitis C virus infection. Leukemia 1997; 11(S3):516-518.

10 Satoh T, Yamada T, Nakano S, Tokunaga O, Kuramochi S, Kanai T, Ishikawa H, Ogihara T: The relationship between primary splenic lymphoma and chronic liver disease associated with hepatitis C virus infection. Cancer 1997; 80:1981-1988.

11 Mangia A, Clemente R, Musto P, Cascavilla I, Floresta P, Sanpaolo G, Gentile R, Viglotti ML, Facciousso D, Carotenuto M, Rizzetto M, Andriulli A: Hepatitis $\mathrm{C}$ virus infection and monoclonal gammopathies not associated with cryoglobulinemia. Leukemia 1996;10:12091213.
12 Andreone P, Zignego A, Cursaro C, Gramenzi A, Gherlinzoni F, Fiorino S, Giannini C, Boni P, Sabattini E, Pileri S, Tura S, Bernardi M: Prevalence of monoclonal gammopathies in patients with hepatitis $\mathrm{C}$ virus infection. Ann Intern Med 1998;129:294-298.

13 Perrone A, Deramo MT, Spaccavento F, Santarcangelo P, Favoino B, Antonaci S: Hepatitis $\mathrm{C}$ virus (HCV) genotypes, human leucocyte antigen expression and monoclonal gammopathy prevalence during chronic $\mathrm{HCV}$ infection. Cytobios 2001;106(suppl 1):125-134.

14 Tanaka H, Tanabe O, Iwato K, Asaoku H, Noubuyoshi M: Sensitive inhibitory effect of interferon-alpha on M-protein secretion of human myeloma cells. Blood 1989;74:17181722.

15 Chamberlain RW, Adams N, Saeed AA, Simmonds O, Elliot RM: Complete nucleotide sequence of a type 4 hepatitis $C$ virus variant, the predominant genotype in the Middle East. J Gen Virol 1997;78:1341-1347.

16 Hassan F, Askar H, Al Khaldi J, Al Shamali M, Al Kalaoui M, Al Nakib B: Lack of transmission of hepatitis $\mathrm{C}$ virus following needle stick accidents. Hepatogastroenterology 1999;46: 1678-1681.

17 Nkansa-Dwamena D, Mughal H: Monoclonal protein detection at Al-Amiri hospital, Kuwait. KMJ 1997;29:188-190. 